\title{
뉴질랜드 ODA 예산확대 계획
}

\section{I. 서론}

Stephanie Lee 뉴질랜드 DAC 대표에 의하면, 뉴 질랜드 정부는 2005 06 회계년도 ODA 예산을 $21 \%$ (약 43 백만미불) 확대할 계획이며, 이는 최근 10 여년간 최대의 인상폭이라고 함.

- 4.13 뉴질랜드 원조정책 검토회의시 DAC는 개 발원조전담기관 NZAID 설립을 긍정평가하였 으나, ODA/GNI 비율이 $0.23 \%$ 로서 $\mathrm{DAC}$ 국가 들의 평균에 미달한다고 지적하면서 원조규모 확대를 권고한 바 있음.

\section{II. 본론}

이로써 뉴질랜드 정부는 2005 6년도 ODA 규모 를 272 백만미불(383백만뉴불)로 확대하여 $\mathrm{GNI}$ 의 $0.27 \%$ 가 되도록 하고, 2006 07 회계연도에는
$0.27 \%$ 를 유지하며, 2007 08년도에는 다시 $0.28 \%$ 로 올릴 계획이라고 함.

\section{III. 결론}

ㅁ 뉴질랜드 ODA 예산은 외교부 예산과 별도로 배정 되며, 외교통상부 예산 181백만미불(254백만뉴불) 에 비해 $\mathrm{ODA}$ 예산이 1.5 배에 달한다고 하는 바, 우리나라의 경우 KOICA 예산이 외교부 예산안에 편성되어 있으며 규모면에서도 외교부 전체 예산 의 $15 \%$ 에 불과한 실정임을 감안, 시사하는 바가 크다고 사료됨.

[자료:주오이시디 대표부] 